\title{
Relationship between pit slope design and coal reserve estimation in Pit X, Muara Enim, South Sumatra Province
}

\author{
Taufiq Muhammad Wijayanto ${ }^{1 *}$, Wahyu Wilopo ${ }^{1}$, I Gede Budi Indrawan ${ }^{1}$, and Sunarko ${ }^{2}$ \\ ${ }^{1}$ Geological Engineering Department, Universitas Gadjah Mada, Indonesia \\ ${ }^{2} \mathrm{PT}$. Bukit Asam Tbk., Indonesia
}

\begin{abstract}
Mine planning is an important part of mining activity. Improper mine plan will increase production costs, non-optimal extraction of mines and safety factors that do not meet the standard. One of the most important aspects before undertaking mine plan is determining the optimal slope design as a basis for making mine pits for coal extraction. This study aims to estimate the maximum reserves that can be taken from the mine pit by taking account of the safety factor of the pit slope design. The study was conducted using drill log data and rock engineering characteristics. Analysis of slope stability is done using the Rocscience Slide V.6 software while coal reserves estimation is done using Minescape V.5.2. Slope stability analysis is modeled with several scenarios of slope angles until a single optimal slope angle is obtained, with the value of the slope safety factor that meets the safety criteria. The results showed that the maximum single slope angle in a safe pit was $52^{\circ}$ with a safety factor of 1.266 , while the coal reserves obtained with the said slope angle are $29,965,008$ tons.
\end{abstract}

\section{Introduction}

\subsection{Background}

Indonesia is one of the countries that has considerable coal reserves of 37 billion tons [1]. Along with the decreasing of oil and gas energy, coal is one of the alternative energy sources that are very potential to be developed in Indonesia. This condition causes many business people to build coal mining companies [2]. In 2019 PT. Bukit Asam is capable of producing 28.5 million tons of coal, and in 2020 the production target is increased to 30 million tons.

The stability of the slope at the mine pit is closely related to the ground movement. Soil movement is a variety of processes that produce downward and outward movements of slope-forming materials, including rocks, soil, pile materials, or a combination of all these materials [3]. Landslide generally occurs if the slope is not able to withstand the weight of the topsoil because of an additional load on the surface of the slope and the reduction of binding capacity between the relief soil grains.

The increasing coal production figures demand optimization in mining activities. Therefore, one of the efforts that can be done to increase coal production figures is to optimize the slope of the mine by taking into account the safety factor. This study aims to estimate coal reserves that can be mined in a safe condition, so that any unwanted accidents that can reduce any production figures can be avoided. The research can be used as a reference in designing mines to support the target of coal production.

\subsection{Description of the research area}

This research was conducted in the Muara Enim Regency, South Sumatra Province, Indonesia, with an area of around $7,384 \mathrm{~km}^{2}$. Now this area is a mining area managed by PT Bukit Asam Tbk, as shown in Figure. 1.

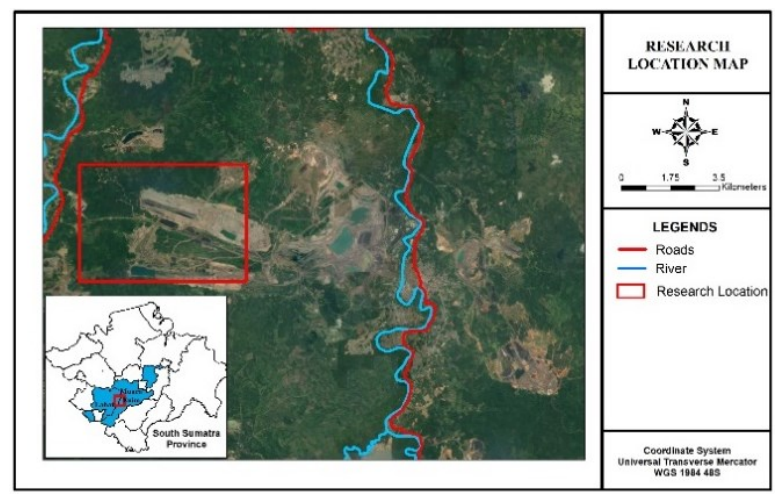

Fig. 1. Research area location in Muara Enim Regency

\section{Geological background}

Physiographically, the research area is located in the South Sumatra Basin [4]. The South Sumatra Basin is a back-arc basin that is formed during the east-west

\footnotetext{
${ }^{*}$ Corresponding author: taufiq.wijayanto@mail.ugm.ac.id
} 
trending extension phase formed during the pre-tertiary and early tertiary ages [5].

Coal in the research area is part of the Miocene Muara Enim Formation, formed during the regression phase of the Neogen deposition cycle [6]. Each seam is widely distributed and has a regular pattern of thickness, ash content, and splitting. The condition of the regional coal formation in this area is controlled by the burial process [6].

The economic coal seam is located in the Muara Enim Formation [7]. Stratigraphically, the study area is divided into several layers of coal, which are Mangus coal (Seam A), Suban coal (Seam B), and Petai coal (Seam C) as shown in Figure. 2. At the study site, the Mangus coal seam divided into two coal seams, namely Seam A1 and Seam A2. [8] Explains that the Muara Enim Formation coal seam is as follows:

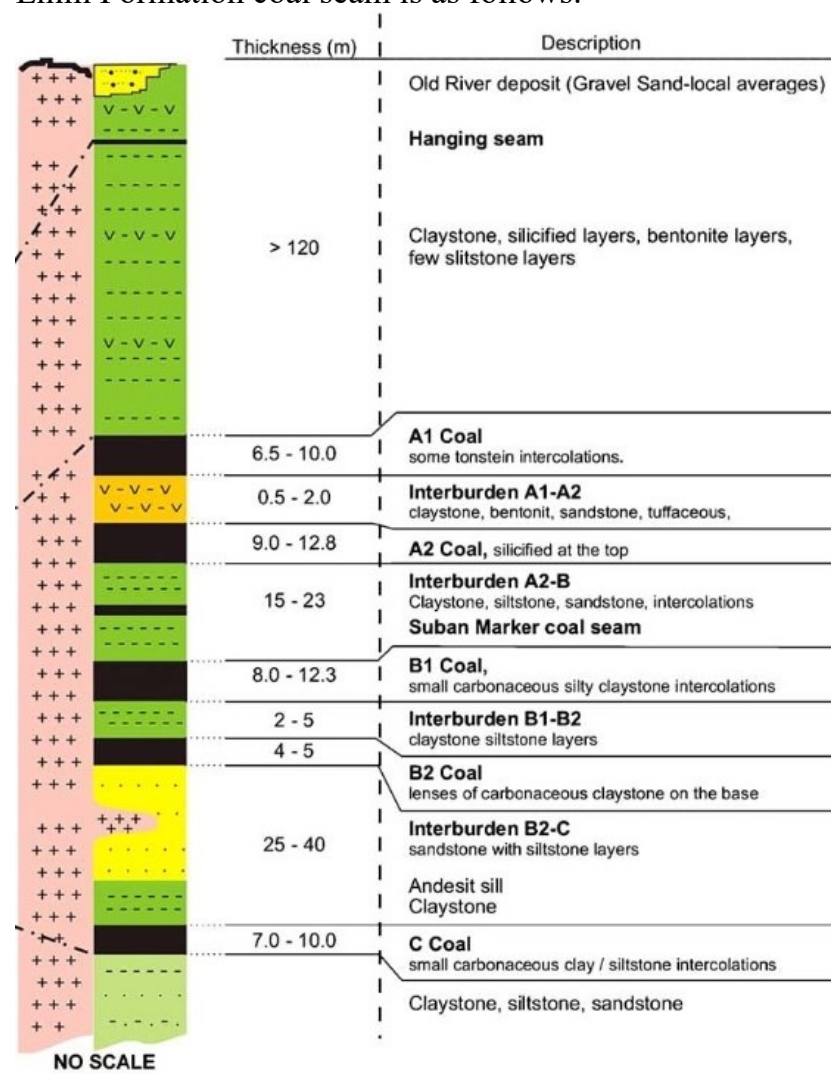

Fig. 2. Stratigraphy of the Muara Enim Formation [8]

Seam A1 (Upper Mangus) consists of bright-banded coal with dull and bright coal lamination near the bottom and dull coaly claystone coal at the [8]. Seam A1 also has three parting that consist of pelletoidal claystone, commonly referred to as tonsteins. Coal seam thickness varies from $2.5 \mathrm{~m}$ high in the intrusion zone to $9.83 \mathrm{~m}$ in the low-rank coal area.

Seam A2 (Lower Mangus) is dominated by brightbanded coal, and its thickness varies from 4 to $13 \mathrm{~m}$. There is also a silicified coal layer which thickness is around $10-20 \mathrm{~cm}$ at the top of the coal seam.

Seam B1 (upper Suban) thickness ranges from 5-14 $\mathrm{m}$, and generally, there is no layer of tonstein as impurities on this layer.

Seam B2 (Lower Suban) thickness ranges from 2-6 $\mathrm{m}$, with a tonstein layer in the middle of the seam. The upper part of the layer consists of bright-banded coal, and the bottom part of the layer consists of dull-banded coal.

Seam C (Petai) thickness ranges from 7-12 m. in this layer, there are four layers of clay with a thickness of 5$15 \mathrm{~cm}$ each. This layer also has higher sulfur content than other coal layers sometimes, pyrite is also visible in the sample.

\section{Research methods}

\subsection{Research data}

Research data comprise of lithology drilling data, topographic data, data parameters of physical and mechanical properties of rock, and seismic constant value data at the study site.

\subsection{Slope stability analysis}

The calculation of the safety factor value is a standard method used to express the stability level of mine slope. This value is the ratio between the retaining forces that held stability in the slope and the driving force that causes landslides. The stability of the mining slope is influenced by many parameters, including slope geometry, water pore pressures, geotechnical properties of the material, and external forces such as vibrations and loading. Bishop introduced the formula of the slope safety factor that used to determine the stability of the slope in the form of soil material in Equation 1.

There are nine methods of slope stability analysis in which most of these methods meet the force balance. From the existing methods, the method of a slice is the most common method used for analyzing slope stability. The slope stability analysis is carried out using the boundary equilibrium method using SLIDE 6.0 software. Single slope angles were modeled start with a single slope angle of $45^{\circ}$ and then simulations of increasingly steep slopes to find the optimal slope angle that meets the recommended safety factor values according to [9], as shown in Table 1 .

Table 1. Relationship between safety factor and landslide intensity [9]

\begin{tabular}{cc}
\hline Safety Factor & Event \\
\hline $\mathrm{SF}<1.07$ & Landslide often occurred \\
$1.07<\mathrm{SF}<1.25$ & Landslide ever occurred \\
$\mathrm{SF}>1.25$ & Landslide rarely occurred \\
\hline
\end{tabular}

The simplified Bishop method is the most popular in slope stability analysis. The assumption used in this method is that the value of the inter-slice shear force is equal to zero $(X=0)$, and the collapse plane is in the form of a circular arc. The equilibrium conditions that can be fulfilled by this method are that the equilibrium moment at the center of the collapsing circle for each slice and the force balance in the vertical direction for each slice, while the force balance in the horizontal direction cannot be fulfilled.

The Equation 1 is used for calculating the slope stability of the Bishop method based on [10]. 


$$
S F=\frac{\sum \mathrm{X} /(1+\mathrm{Y} / \mathrm{FK})}{\sum \mathrm{Z}+\mathrm{Q}}
$$

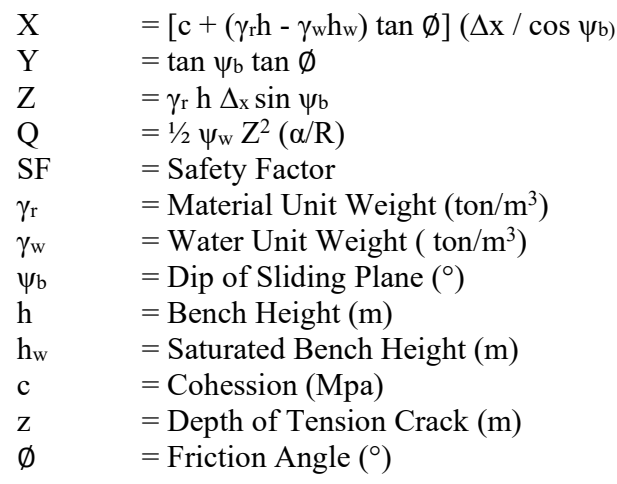

\subsection{Reserve estimation}

In the determination of mined reserves, it is almost impossible to obtain $100 \%$ of mined reserves from in situ reserves, where dilution will occur during the mining phase [11]. Excavation estimation using the block method can be done by making imaginary lines in the area of the calculated objects. In general, this block method is used for ore that have a thickness with high homogeneity with a reasonably even distribution area such as coal [12].

Before starting to estimate a value of mined reserves, according to [11], there are two main factors that must be quantified, namely the limiting factor of reserves and the Losses Factor. After knowing the losses factors that affect the calculation of reserves in a coal seam, the calculated reserves can be calculated by the Equation 2 [13]:

$$
\text { Coal Tonnage }=A x B \times C
$$

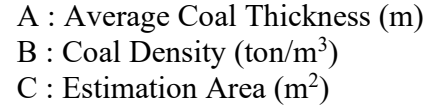

\section{Results and discussion}

\subsection{Geological condition}

According to research conducted by [6], coal deposits in the study area belong to M2 Members, Muara Enim Formation consisting of seam A1, seam A2, seam B, and seam $\mathrm{C}$.

Based on drilling data, stratigraphically, layers above seam A1 are referred to as overburden A1 composed of claystone, then underneath it is seam A1 which has an average thickness of $10.38 \mathrm{~m}$. Underneath them is an inter burden layer A1-A2 composed of sandstones, then underneath the said layer, there is an A2 seam which has an average thickness - an average of $15.44 \mathrm{~m}$. Below A2 seam, there is a layer of inter burden A2-B composed of claystone, then underneath it is seam $\mathrm{B}$, which average thickness is $22.16 \mathrm{~m}$. Beneath seam $\mathrm{B}$, there is a layer of inter burden B-C composed of sandstone, and beneath it is seam $\mathrm{C}$, which has an average thickness of $9.24 \mathrm{~m}$. The lowest layer of this stratigraphy is an under burden $\mathrm{C}$ layer, which composed of clay stones. Modeling results indicate that the condition of coal in the study area has a strike value of $\mathrm{N} 87^{\circ} \mathrm{E}$ and a dip value of around $15-40^{\circ}$ to the south.

\subsection{Slope stability analysis}

From the results of the physical rock test of drilling in the study area, the rock layers of this area can be grouped as in Table 2.

\begin{tabular}{|c|c|c|c|c|}
\hline No & $\begin{array}{l}\text { Stratigraphic } \\
\text { Units }\end{array}$ & $\begin{array}{c}\text { Unit } \\
\text { Weight } \\
\left(\mathbf{k N} / \mathrm{m}^{3}\right)\end{array}$ & $\begin{array}{c}\text { Cohesion } \\
\left(\mathbf{k N} / \mathbf{m}^{2}\right)\end{array}$ & $\begin{array}{l}\text { Phi } \\
\left({ }^{\circ}\right)\end{array}$ \\
\hline 1 & Overburden A1 & 17.94 & 42.03 & 20.87 \\
\hline 2 & Coal A1 & 12.05 & 280.39 & 22.51 \\
\hline 3 & Interburden $\mathrm{A} 1-\mathrm{A} 2$ & 19.24 & 288.53 & 24.47 \\
\hline 4 & Coal A2 & 12 & 284.83 & 21.73 \\
\hline 5 & Interburden A2 - B & 19.57 & 137.33 & 19.7 \\
\hline 6 & Coal B & 11.91 & 170.93 & 21 \\
\hline 7 & Interburden $\mathrm{B}-\mathrm{C}$ & 22.87 & 215.64 & 29.1 \\
\hline 8 & Coal C & 12.07 & 207.85 & 23.01 \\
\hline 9 & Underburden $\mathrm{C}$ & 20.74 & 142.95 & 21.18 \\
\hline
\end{tabular}

Table 2. Rock mechanics characteristics in study area

The results of the characterization of the rock parameters were then inputted into the overall slope stability analysis. For other input parameters such as slope, geometry refers to the company recommendations, while the ground water level refers to [14], which is $2 / 3$ of the slope height and seismic constant refer to [1], which is $0.02 \mathrm{~g}$. Slope stability analysis is carried out on 5 sections at each corner of the highwall slope (south slope) and 4 sections on the lowwall slope (north slope). These sections are considered to represent the pit condition from west to east as shown in Figure. 3. The example of the calculation results of safety factors is shown in Figure. 4.

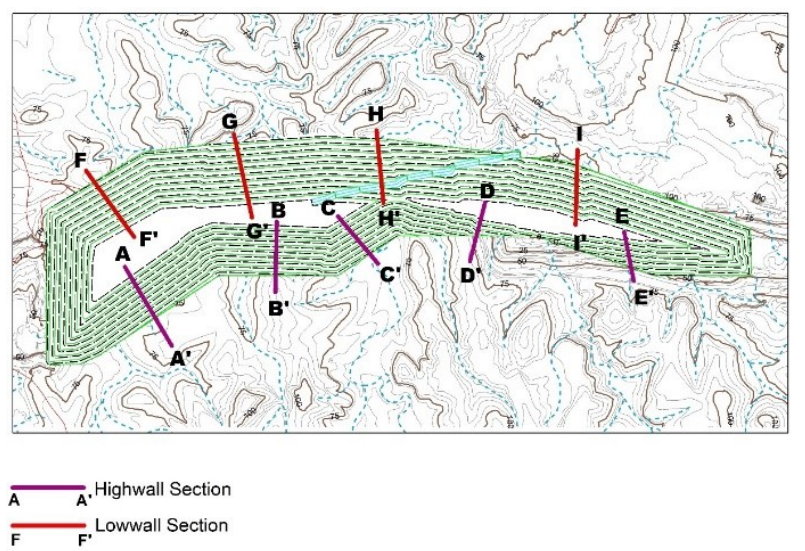

Fig. 3. Map of slope stability analysis section

Slope stability analysis results with various variations of the single slope angle and overall slope obtained the value of safety factor as shown in Table 3 . The most optimal value of the slope angle that can be applied is with a single slope angle value of $52^{\circ}$, with a safety factor value of 1.266 . 


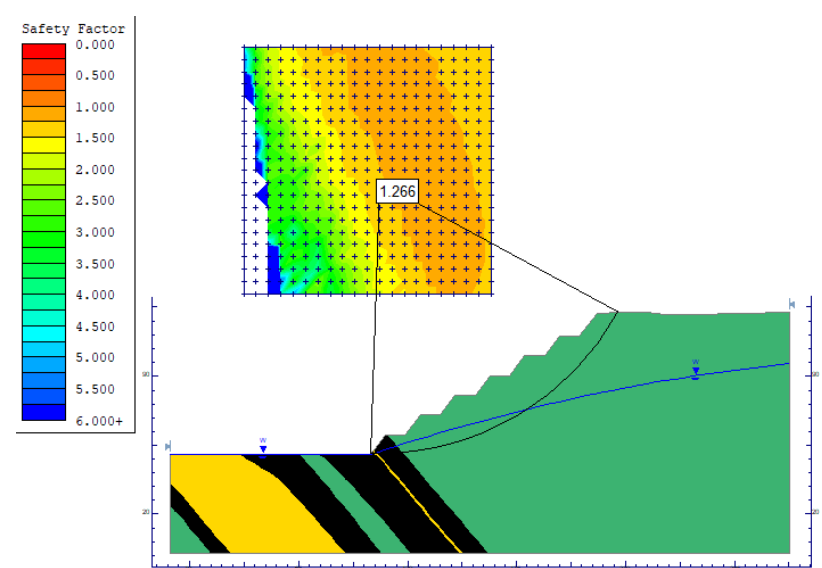

Fig. 4. One of the slope stability analysis result in section e with slope angle $52^{\circ}$ in section e with earthquake load

Table 3. Slope safety factor with various angle design

\begin{tabular}{cccccc}
\hline No & Side Wall & $\begin{array}{c}\text { Single } \\
\text { Slope } \\
\left({ }^{\circ}\right)\end{array}$ & $\begin{array}{c}\text { Bench } \\
\text { Height } \\
(\mathbf{m})\end{array}$ & $\begin{array}{c}\text { Bench } \\
\text { Width } \\
(\mathbf{m})\end{array}$ & $\begin{array}{c}\text { Safety } \\
\text { Factor }\end{array}$ \\
\hline 1 & & 30 & 10 & 10 & 1.679 \\
2 & & 32 & 10 & 10 & 1.638 \\
3 & & 35 & 10 & 10 & 1.566 \\
4 & & 37 & 10 & 10 & 1.539 \\
5 & & 40 & 10 & 10 & 1.533 \\
6 & Highwall & 42 & 10 & 10 & 1.527 \\
7 & (Section E) & 45 & 10 & 10 & 1.458 \\
8 & & 47 & 10 & 10 & 1.397 \\
9 & & 50 & 10 & 10 & 1.299 \\
10 & & 52 & 10 & 10 & 1.266 \\
11 & & 53 & 10 & 10 & 1.248 \\
12 & & 55 & 10 & 10 & 1.223 \\
\hline 13 & Lowwall & 25 & 10 & 10 & 1.330 \\
\hline
\end{tabular}

$\mathrm{SF}<1.25$
The results of the slope analysis with various single slope and overall slope angles can be obtained the value of the safety factor as the following table. The most optimal slope angle values that can be applied are with a single slope angle of $52^{\circ}$ and overall slope $32^{\circ}$

\subsection{Reserve estimation}

Reserves estimation needs to consider the minimum coal thickness for estimations which is $>0.4$ meters for hard coal and $>1$ meter for brown coal [15]. Therefore, based on the coal thickness statistics from drilling results in Table 4, the reserves estimation can be done since coal thickness meets all the requirements. To estimate coal reserves, pit designs need to be made first with maximum stripping value is 2.66 [16]. According to company regulations, the parameter in designing pits needs to consider aspects of the slope geometry in the form of a width of 10 meters and a height of 10 meters, and the width of the haul road is 30 meters based on the calculation of the total width of the haul road needed, namely HD-785. The value of the slope angle is varied to see the difference in the amount of reserves as shown in Table 5. The results obtained from the reserves estimation is that the optimal volume that can be mined from the design using a single slope angle of $52^{\circ}$ is $29,965,008$ tons of coal.

Table 4. Recapitulation results of coal thickness statistical analysis by drilling

\begin{tabular}{cccccccc}
\hline \multirow{2}{*}{ Seam } & \multicolumn{7}{c}{ Statistical analysis parameters } \\
\cline { 2 - 8 } & $\begin{array}{c}\text { Data } \\
\text { Amount }\end{array}$ & $\begin{array}{c}\text { Maximum } \\
(\mathbf{m})\end{array}$ & $\begin{array}{c}\text { Minimum } \\
(\mathbf{m})\end{array}$ & $\begin{array}{c}\text { Range } \\
(\mathbf{m})\end{array}$ & $\begin{array}{c}\text { Average } \\
(\mathbf{m})\end{array}$ & $\begin{array}{c}\text { Median } \\
(\mathbf{m})\end{array}$ & $\begin{array}{c}\text { Std. } \\
\text { Deviation }\end{array}$ \\
\hline $\mathrm{A} 1$ & 30 & 36.3 & 5.4 & 30.9 & 10.38 & 8.50 & 6.27 \\
$\mathrm{~A} 2$ & 33 & 35.7 & 6.35 & 29.35 & 15.44 & 12.65 & 6.9 \\
$\mathrm{~B}$ & 33 & 49.5 & 12.5 & 36.99 & 22.16 & 17.40 & 9.23 \\
$\mathrm{C}$ & 27 & 15.28 & 6.45 & 8.83 & 9.24 & 8.45 & 2.31 \\
\hline
\end{tabular}

Table 5. Recapitulation of coal reserves in research areas

\begin{tabular}{cccccc}
\hline No & Seam & Slope & $\begin{array}{c}\text { Safety } \\
\text { Factor }\end{array}$ & Reserves & Total \\
\hline 1 & A1 & 30 & 1.679 & $2,368,812$ & \\
2 & A2 & 30 & 1.679 & $4,973,695$ & $25,665,851$ \\
3 & B & 30 & 1.679 & $10,992,453$ & \\
4 & C & 30 & 1.679 & $7,330,891$ & \\
\hline 5 & A1 & 32 & 1.638 & $2,389,092$ & \\
6 & A2 & 32 & 1.638 & $5,043,478$ & $25,908,358$ \\
7 & B & 32 & 1.638 & $11,141,886$ & \\
8 & C & 32 & 1.638 & $7,333,901$ & \\
\hline 9 & A1 & 35 & 1.566 & $2,493,510$ & \\
10 & A2 & 35 & 1.566 & $5,244,400$ & $26,761,382$ \\
11 & B & 35 & 1.566 & $11,505,885$ & \\
12 & C & 35 & 1.566 & $7,517,586$ & \\
\hline 13 & A1 & 37 & 1.539 & $2,546,982$ & $27,158,171$ \\
\cline { 4 - 5 } & & & & & \\
& & & &
\end{tabular}

Table 5. Recapitulation of coal reserves in research areas

\begin{tabular}{cccccl}
\hline 14 & A2 & 37 & 1.539 & $5,347,538$ & \\
15 & B & 37 & 1.539 & $11,684,641$ & \\
16 & C & 37 & 1.539 & $7,579,010$ & \\
\hline 17 & A1 & 40 & 1.533 & $2,657,005$ & \\
18 & A2 & 40 & 1.533 & $5,552,640$ & $28,293,720$ \\
19 & B & 40 & 1.533 & $12,083,195$ & \\
20 & C & 40 & 1.533 & $8,000,880$ & \\
\hline 21 & A1 & 42 & 1.527 & $2,703,805$ & \\
22 & A2 & 42 & 1.527 & $5,626,672$ & $28,525,028$ \\
23 & B & 42 & 1.527 & $12,135,876$ & \\
24 & C & 42 & 1.527 & $8,058,676$ & \\
\hline 25 & A1 & 45 & 1.458 & $2,768,176$ & \\
26 & A2 & 45 & 1.458 & $5,760,959$ & $29,118,950$ \\
27 & B & 45 & 1.458 & $12,438,319$ & \\
28 & C & 45 & 1.458 & $8,151,496$ & \\
\cline { 2 - 4 } & & & & &
\end{tabular}


Table 5. Recapitulation of coal reserves in research areas

\begin{tabular}{|c|c|c|c|c|c|}
\hline 29 & A1 & 47 & 1.397 & $2,813,492$ & \multirow{4}{*}{$29,301,738$} \\
\hline 30 & A2 & 47 & 1.397 & $5,804,181$ & \\
\hline 31 & B & 47 & 1.397 & $12,489,052$ & \\
\hline 32 & $\mathrm{C}$ & 47 & 1.397 & $8,195,014$ & \\
\hline 33 & $\mathrm{~A} 1$ & 50 & 1.299 & $2,869,910$ & \multirow{4}{*}{$29,767,445$} \\
\hline 34 & A2 & 50 & 1.299 & $5,912,256$ & \\
\hline 35 & B & 50 & 1.299 & $12,689,029$ & \\
\hline 36 & $\mathrm{C}$ & 50 & 1.299 & $8,296,251$ & \\
\hline 37 & A1 & 52 & 1.266 & $2,875,534$ & \multirow{4}{*}{$29,965,008$} \\
\hline 38 & A2 & 52 & 1.266 & $5,973,604$ & \\
\hline 39 & B & 52 & 1.266 & $12,810,472$ & \\
\hline 40 & $\mathrm{C}$ & 52 & 1.266 & $8,305,398$ & \\
\hline 41 & A1 & 53 & 1.248 & $2,894,740$ & \multirow{4}{*}{$30,090,685$} \\
\hline 42 & A2 & 53 & 1.248 & $6,004,362$ & \\
\hline 43 & B & 53 & 1.248 & $12,860,369$ & \\
\hline 44 & $\mathrm{C}$ & 53 & 1.248 & $8,331,214$ & \\
\hline 45 & A1 & 55 & 1.223 & $2,932,539$ & \multirow{4}{*}{$30,452,632$} \\
\hline 46 & A2 & 55 & 1.223 & $6,106,082$ & \\
\hline 47 & B & 55 & 1.223 & $13,047,333$ & \\
\hline 48 & $\mathrm{C}$ & 55 & 1.223 & $8,366,679$ & \\
\hline
\end{tabular}

\subsection{Relationship between slope design and reserve estimation}

From the results of the research, it is shown that the design of the slope geometry affects the amount of coal reserves that can be mined, where the greater the angle of the slope, the greater volume of reserves that can be taken. This relationship can be seen in Figure. 5. Likewise, the correlation between angle and safety factor is also known as shown in Table 3, that as the angle of slope is getting steeper, safety factor will be getting smaller. It is recommended that the pit design use a single slope angle of $52^{\circ}$ as the maximum limit for a slope design, because if it exceeds that value the safety factor value will be $<1.25$ as it would be unsafe to conduct mining activities under the said value.

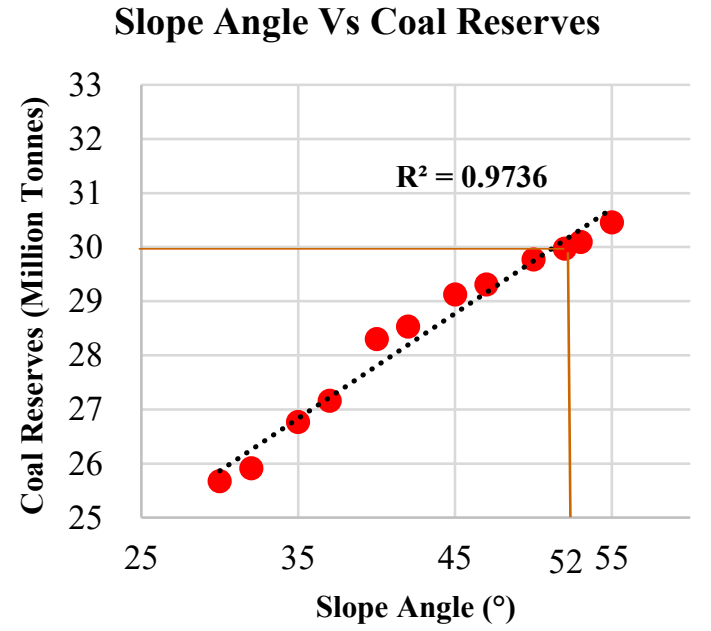

Fig. 5. Relationship between single slope angle and coal reserves.

\section{Conclusion}

The slope design is very important in mine pits designs because in the construction of mine pits it is necessary to consider the safety of the slope. Bench slope design also affects the amount of reserves that can be taken. The results showed that there was a relationship between slope design and the amount of coal reserves that could be taken, as the higher the angle of the slope, the greater the amount of the coal that could be taken. The results of this study recommended using a single slope angle of $52^{\circ}$ with a safety factor value of 1.266 since this is the most optimal slope design that produces total coal reserves of $29,965,008$ tons of coal.

We would like thanks to Mr. Eko Pujiantoro as the Long-Term Planning Manager of PT. Bukit Asam that permitted to conduct this research and publication the result of the research. We also want to thank the Department of Geological Engineering for supporting the research.

\section{References}

1. K. Oktaviani, Rekonsiliasi Data, Sumber Daya Batubara Indonesia Kini 166 Miliar Ton, Cadangan 37 Miliar Ton: https://www.esdm.go.id/id/mediacenter/arsip-berita/rekonsiliasi-data-sumber-dayabatubara-indonesia-kini-166-miliar-ton-cadangan37-miliar-ton (Accessed June 2019)

2. D. Saputra, M. Asof, and E.D.H. Wiwik, Rancangan Teknis Penambangan Batubara Di Blok Selatan PT. Dizamatra Powerindo Lahat Sumatera Selatan: Jurnal Ilmu Teknik Vol. 2, No. 3, p. 1 - 9 (2014), In Bahasa

3. D. M. Cruden and D.J. Varnes. Landslide Types and Processes. In: Turner, A.K. and Shuster, R.L., Landslides: Investigation and Mitigation: Transportation Research Board, Special Report No. 247, 36-75 (1996)

4. M. G. Bishop, South Sumatra Basin Province, Indonesia: The Lahat/Talang Akar Cenozoic Total Petroleum System: U.S. Geological Survey Open File Report, 22 p (2001)

5. C. D. Wyllie and C.W. Mah, Rock Slope Engineering: Civil and Mining 4th Edition: United States of America, Taylor \& Francis, p. 431 (2004)

6. R. Susilawati, and C.R Ward, Metamorphism of mineral matter in coal from the Bukit Asam deposit, South Sumatra, Indonesia: Int. J. Coal Geol. 68, p. 171 - 195 (2006)

7. Subastedjo, Penyelidikan Geologi Untuk Perencanaan Tambang Batubara: Conto Kasus Perencanaan Tambang Batubara Muara Tiga, Bukit Asam, Sumatra Selatan: PIT XII Ikatan Ahli Geologi Indonesia, 13, p. 209 - 213. (1983)

8. R. Susilawati, and C.R Ward, Metamorphism of mineral matter in coal from the Bukit Asam deposit, South Sumatra, Indonesia: Int. J. Coal Geol. 68, p. 171 - 195 (2006)

9. J. E. Bowles, Physical and Geotechnical Properties of Soils: Japan, McGraw-Hill, 478 p. (1979) 
10. C. D. Wyllie and C.W. Mah, Rock Slope Engineering: Civil and Mining 4th Edition: United States of America, Taylor \& Francis, p. 431 (2004)

11. A. R. Prinandi, Perancangan (Design) Pit Ef Pada Penambangan Batubara di PT Milagro Indonesia Mining Desa Sungai Merdeka, Kecamatan Samboja, Kabupaten Kutai Kartanegara Provinsi Kalimantan Timur: Prosiding Teknik Pertambangan, Vol 1, p. 101 - 109 (2015), In Bahasa

12. A. D. Laksono, A.M. Muchsin, dan D. Guntoro, Permodelan dan Estimasi Sumberdaya Batubara (Studi kasus wilayah IUP CV. Atap Tri Utama Kecamatan Muarajawa, Kabupaten Kutai Kartanegara, Provinsi Kalimantan Timur): Prosiding Teknik Pertambangan, p. 49 - 56 (2018), In Bahasa

13. G. H. Wood Jr, T.M. Kehn, M.D Carter, and W.C. Culbertson, Coal Resource Classification System of the U.S. Geological Survey: United States of America, United States Geological Survey, 65 p (1983)

14. J. A. Fleurisson. Slope Design and Implementation in Open Pit Mines, Geological and Geomechanical Approaches: Procedia Eng. 46: p. 27 - 38 (2012)

15. Badan Standarisasi Nasional, Pedoman Pelaporan, Sumberdaya dan Cadangan Mineral. SNI 13-60111999: Standar Nasional Indonesia, p. 1 - 16 (1999), In Bahasa

16. T. M. Wijayanto, Desain Pit Tambang dan Perencanaan Operasional Produksi Tambang Batubara Unit Pertambangan Tanjung Enim PT. Bukit Asam, Tbk (Unpublished Master Thesis): Universitas Gadjah Mada (2020) 